\title{
Euglossine bee communities in small forest fragments of the Atlantic Forest, Rio de Janeiro state, southeastern Brazil (Hymenoptera, Apidae)
}

\author{
Willian Moura de Aguiar ${ }^{1,2} \&$ Maria Cristina Gaglianone ${ }^{2}$
}

${ }^{1}$ Laboratório de Estudos Ambientais, Programa de Pós-Graduação em Modelagem em Ciências da Terra e do Ambiente, Universidade Estadual de Feira de Santana. BR 116, Km 03, Campus Universitário, Feira de Santana-BA, 44031-460.wmag26@yahoo.com.br

${ }^{2}$ Laboratório de Ciências Ambientais, Programa de Pós-Graduação em Ecologia e Recursos Naturais, Universidade Estadual do Norte Fluminense Darcy Ribeiro. Av. Alberto Lamego, 2000, Parque Califórnia, Campos dos Goytacazes-RJ, 28013-602. mcrisgag@uenf.br

\begin{abstract}
Euglossine bee communities in small forest fragments of the Atlantic Forest, Rio de Janeiro state, southeastern Brazil (Hymenoptera, Apidae). Euglossine bees are important pollinators in forests and agricultural areas. Although the structure of their communities is critically affected by anthropogenic disturbances, little is known about these bees in small forest fragments. The objectives of this study were to analyze the composition, abundance, and diversity of euglossine bee species in nine small fragments of different phytophysiognomies of the Atlantic Forest in southeastern Brazil, and to identify the environmental variables that may be related to the species composition of these communities. Males were sampled quarterly from May 2007 to May 2009 with aromatic traps containing methyl cinnamate, vanillin, eucalyptol, benzyl acetate, and methyl salicylate. A total of 1558 males, belonging to 10 species and three genera of Euglossina were collected. The richness ranged from five to seven species per fragment. Euglossa cordata, E. securigera, Eulaema nigrita e E. cingulata were common to all fragments studied. The diversity differed significantly among areas, ranging from $\mathrm{H}^{\prime}=1.04$ to $\mathrm{H}^{\prime}=1.65$. The precipitation, phytophysiognomy, and altitude had the highest relative importance over the species composition variation. The results presented in this study demonstrate that small forest fragments are able to support populations of euglossine bee species, most of which are widely distributed and reportedly tolerant to open and/or disturbed areas and suggest that the conservation of such areas is important, particularly in areas that are regenerating and in regions with agricultural matrices where these bees can act as important pollinators.
\end{abstract}

KEYWORDS. Chemical baits; fragmentation; loss habitat; orchid bees; solitary bees.

RESUMO. Comunidade de abelhas Euglossina em pequenos fragmentos de Mata Atlântica no estado do Rio de Janeiro, sudeste do Brasil (Hymenoptera, Apidae). Abelhas Euglossina são importantes polinizadores nas florestas e em áreas agrícolas. Embora a estrutura dessas comunidades seja criticamente afetada por perturbações antrópicas, pouco é conhecido a respeito destas abelhas em pequenos fragmentos florestais. Os objetivos deste estudo foram analisar a composição, abundância e diversidade de espécies em nove pequenos fragmentos florestais de diferentes fitofisionomias no sudeste do Brasil, e identificar as possíveis variáveis ambientais que podem estar relacionadas à composição de espécies de Euglossina. Os machos foram amostrados trimestralmente de maio/07 a maio/09 com o auxílio de armadilhas aromáticas contendo cinamato de metila, vanilina, eucaliptol, acetato de benzila e salicilato de metila. Foram amostrados 1558 machos de três gêneros e 10 espécies. A riqueza variou de cinco a sete espécies por fragmento. Euglossa cordata, E. securigera, Eulaema cingulata e E. nigrita foram comuns a todos os fragmentos estudados. A diversidade diferiu significativamente entre as áreas estudadas, variando de $\mathrm{H}^{\prime}=1.04$ até $\mathrm{H}^{\prime}=1.65$. A precipitação, o tipo fitofisionômico e a altitude tiveram alta importância relativa sobre a variação da composição de espécies. Os resultados apresentados neste estudo demonstram que pequenos fragmentos podem suportar populações de abelhas Euglossina que, em sua maioria, são amplamente distribuídas e supostamente tolerantes a ambientes abertos e perturbados e sugerem que a conservação dessas áreas pode ser de grande importância, principalmente em regiões em processo de regeneração e com matrizes agrícolas, onde essas abelhas podem atuar como polinizadores.

PALAVRAS-CHAVE. Abelhas de orquídeas; abelhas solitárias; fragmentação; iscas aromáticas; perda de habitat.

The Atlantic Forest comprises different ecosystems of great ecological importance and is considered one of the principal conservation hotspots due to its high level of endemism and elevated number of threatened species (Myers et al. 2000). The Atlantic Forest has been subjected to constant aggression since the colonial period, and particularly from the 1960 s to the 1980 s with the recent period of expansion of agriculture and industrialization happened in Brazil (Rizzini 1979; Fundação SOS Mata Atlântica \& INPE 2008). Today less than $8 \%$ of the forest's original area has been preserved (Fundação SOS Mata Attântica/INPE 2011) and most of the remaining forests, especially in areas of intense agriculture, are less than 10 ha, isolated, highly disturbed, little studied, and unprotected (Rocha et al. 2003).
Environmental changes caused by anthropic activities, particularly the fragmentation and habitat loss, are considered the main cause of the decline of pollinators (Aizen \& Feinsinger 2003; Fahrig 2003; Goulson et al. 2008; Winfree et al. 2009; Potts et al. 2010). Insects, more specifically bees, are the principal pollinators of native and cultivated plants. Alterations in the environment such as the fragmentation and habitat loss promote consequences among pollinators that are still not fully understood (Potts et al. 2010).

Bees belonging to the subtribe Euglossina (sensu Silveira et al. 2002) are important pollinators in tropical and subtropical forests (Dressler 1982; Roubik \& Hanson 2004), where they may pollinate plants from more than 40 botanical families, including species of economic interest. Interac- 
tion with certain species is quite limited, as in the case of Orchidaceae, in which case approximately 700 species are exclusively dependent on these insects for their pollination (Dressler 1982; Mori \& Boeke 1987; Maués 2002; Cameron 2004; Roubik \& Hanson 2004).

Several studies have investigated the impact of fragmentation and habitat loss on euglossine bee communities (Becker et al. 1991; Morato 1994; Tonhasca et al. 2002; Sofia \& Suzuki 2004; Brosi 2009; Ramalho et al. 2009; Nemésio \& Silveira 2010). The results obtained in some of these studies suggested a negative effect of the fragmentation on populations of some species, which could lead to a decline of the abundance and species richness of these bees (Powell \& Powell 1987; Morato 1994; Sofia \& Suzuki 2004; Ramalho et al. 2009; Nemésio \& Silveira 2010).

In recent decades, the results of a growing number of studies have demonstrated that the conservation value of small fragments must not be ignored (Tscharntke et al. 2002). Small forest fragments can increase landscape connectivity (Dunning et al. 1992) and provide the habitats for animal species (for example, birds: Fischer \& Lindenmayer 2002; beetles: Estrada \& Coates-Estrada 2002; butterflies: Benedick et al. 2006) and the maintenance of ecological services such as pollination (Bodin et al. 2006).

Studies dealing with the importance of forest fragments as sources of pollinators for agricultural crops demonstrate that these remaining forests provide such plantations with greater richness and abundance of pollinating agents, and increased pollination efficiency (Ricketts 2004; Chacoff \& Aizen 2006; Benevides et al. 2009). Thus, the conservation of forest fragments should be encouraged in agricultural regions, especially in the Atlantic Forest, where the majority of fragments are found on small rural properties with diverse agricultural activities (Rocha et al. 2003; Fundação SOS Mata Atlântica \& INPE 2008).

Despite the recognized importance of euglossine bees as pollinating agents, few studies (Tonhasca et al. 2002; Sofia \& Suzuki 2004; Ramalho et al. 2009; Nemésio \& Silveira 2010) have analyzed the euglossine bee community in small forest fragments under the domain of the Atlantic Forest. Therefore, the objectives of this work were to: 1) comparatively analyze the composition, abundance, and diversity of euglossine bee species in small fragments of different formations of the Atlantic Forest in northern Rio de Janeiro state, and 2) identify if abiotic variables (temperature, humidity, precipitation and altitude) and the phytophysiognomic type may be related to the species composition of these communities.

\section{MATERIAL AND METHODS}

Study areas. The study was carried out in nine forest fragments of less than 20 ha under Atlantic Forest domain with different phytophysiognomic formations in the northern and northeastern regions of Rio de Janeiro State, Brazil, in accordance with the classification of Veloso et al. (1991). Two frag- ments (F1 and F2) of seasonal semideciduous lowland forest (SSLF), located in São Francisco de Itabapoana; four fragments (F3, F4, F5 e F6) of submountainous semideciduous seasonal forest (SSSF), in the municipality of São José de Ubá, and three fragments (F7, F8 e F9) of dense mountainous ombrophilous forest (DMOF), in Trajano de Moraes were selected. The distance between the fragments studied varied from 0.05 to $135 \mathrm{~km}$ (Fig. 1). All fragments are composed of secondary forest vegetation and are located on private properties, with the exception of two studied areas, which are located on the grounds of the Municipal Forest Unit of Trajano de Moraes (F7 and F8). The study areas present distinct local characteristics, such as altitude, matrix around, and phytophysiognomy (Table I).

In the SSLF and SSSF region the climate, according to the Köppen classification, is Aw, with elevated temperatures, rainy summers, and dry winters. In the DMOF region the climate is classified as Cwa, with a moderately humid climate, dry winters, and hot summers (Fig. 2).

Sampling protocol. Euglossine males were sampled every three months between 9:00 AM and 3:00 PM from May 2007 to May 2009, totaling 60 sampling hours in 10 days in each area. The captures were realized with aromatic traps containing the following baits as attractants: methyl cinnamate, vanillin, eucalyptol, benzyl acetate, and methyl salicylate, as utilized by Aguiar \& Gaglianone (2008a) and Ramalho et al. (2009). Baits were applied to cotton balls inside the traps, which were placed $1.5 \mathrm{~m}$ from the soil with a minimum distance of $2 \mathrm{~m}$ between each attractant. Captured specimens were deposited in the Zoology Collection of the Environmental Sciences Laboratory of the Universidade Estadual do Norte Fluminense.

Taxonomic identification was performed through comparisons with previously identified material in the above collection, based on taxonomic keys and publications, and by the specialist Dr. Gabriel A.R. Melo (Universidade Federal do Paraná). Taxonomic decisions were based on classification adopted in Moure's Bee Catalogue (Moure et al. 2008).

Data analysis. Species diversity, dominance, and uniformity in species-abundance distribution were calculated, respectively, with the Shannon-Wiener Diversity Index, Berger-Parker Index, and Pielou Index (Magurran 2004).

The equitability of the species distribution in the study areas were analyzed with the Rank-Abundance Plot, whereby species' relative abundances were plotted in decreasing order (Whittaker 1965) and the difference between the curves obtained for the different areas was analyzed with the Kolmogorov-Smirnov Test (Magurran 2004).

The frequency of occurrence (FO) and dominance (D) were calculated according to Bodenheimer (1955) for each species sampled: $\mathrm{FO}=$ (number of samples with the species/ number of samples) $* 100$. When $\mathrm{FO} \geqslant 50 \%$, the species is considered very frequent (vf), when $\mathrm{FO}<50 \%$ and $\geqslant 25 \%$, the species is frequent ( $\mathrm{f}$ ), when $\mathrm{FO}<25 \%$, the species is labeled infrequent (in). Dominance was calculated as: $\mathrm{D}=(\text { Abundance of species } \mathrm{i} / \text { total abundance })^{*} 100$. When $D \geqslant 5 \%$, the species is considered dominant $(d)$, when 

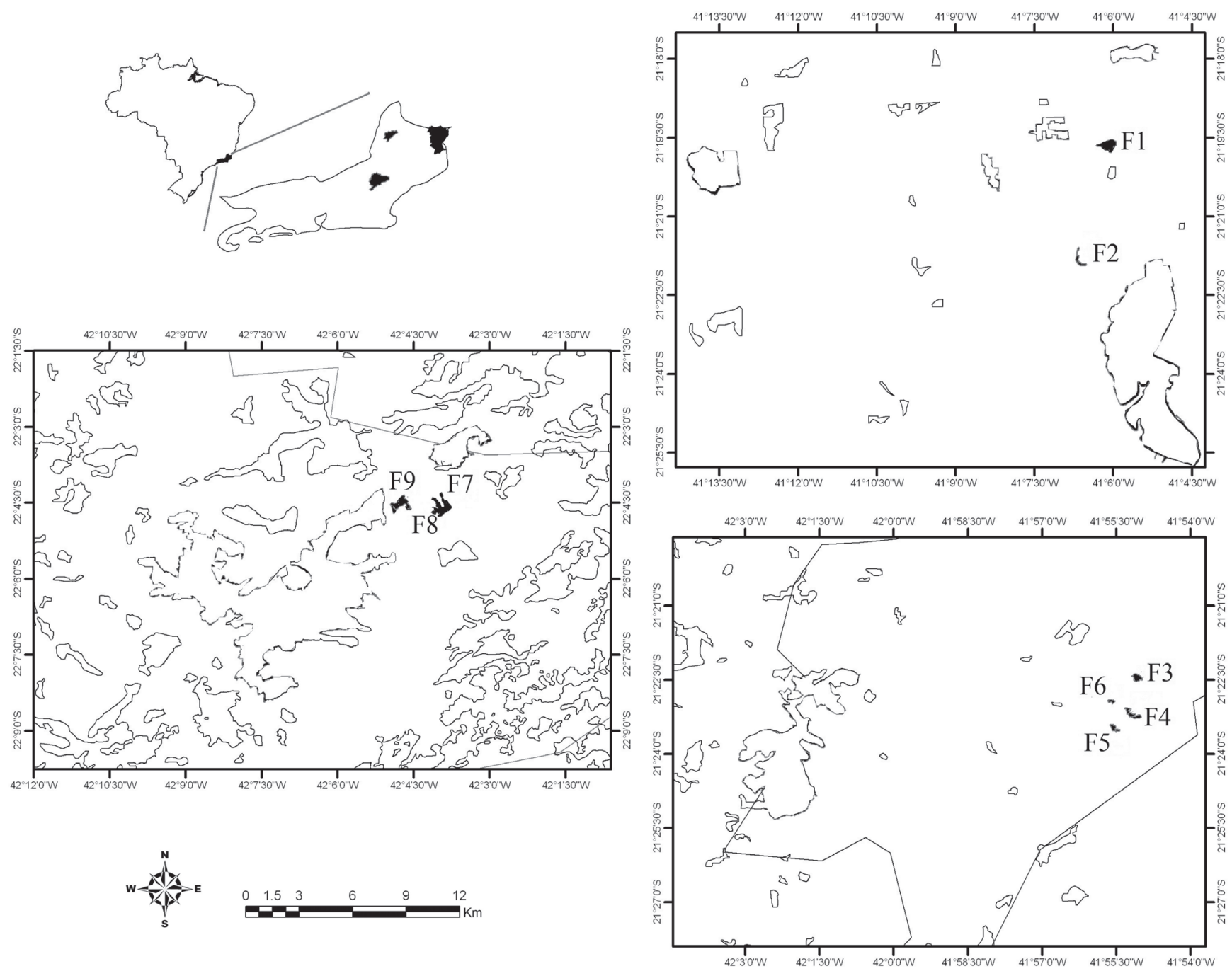

Fig. 1. Location of the nine small forest fragments studied for the Euglossine bee communities in Rio de Janeiro state, southeastern Brazil, from May/ 2007 to May/2009. Black areas indicate fragments studied, outlined areas indicate fragments nearby.

Table I. Location of the study areas, phytophysiognomic type, fragment sizes, altitude, and type of matrix surrounding each forest fragment. SFI: São Francisco de Itabapoana, RJ, SJU: São José de Ubá-RJ and TRJ: Trajano de Moraes, RJ. SSLF: seasonal semideciduous lowland forest; SSSF: submountain semideciduous seasonal forest and DMOF: dense mountainous ombrophilous forest.

\begin{tabular}{|c|c|c|c|c|c|c|}
\hline Areas & Municipality & Coordinates & Size (ha) & Phytophysiognomy & Altitude (m) & Matrix \\
\hline F1 & SFI & $21^{\circ} 19^{\prime} 36^{\prime \prime S} 41^{\circ} 06^{\prime} 04^{\prime \prime} \mathrm{W}$ & 16.0 & SSLF & 40 & Sugarcane, coconut, mango, manioc, and passionfruit \\
\hline $\mathrm{F} 2$ & SFI & $21^{\circ} 21^{\prime} 53^{\prime \prime} \mathrm{S} 41^{\circ} 06^{\prime} 04^{\prime \prime} \mathrm{W}$ & 5.5 & SSLF & 16 & Pasture and sugarcane \\
\hline F3 & SJU & $21^{\circ} 23^{\prime} 30^{\prime \prime} \mathrm{S} 41^{\circ} 55^{\prime} 30^{\prime \prime} \mathrm{W}$ & 4.0 & SSSF & 200 & Pasture, tomato, and bell pepper \\
\hline $\mathrm{F} 4$ & SJU & $21^{\circ} 22^{\prime} 31^{\prime \prime S} 41^{\circ} 55^{\prime} 04^{\prime \prime W}$ & 7.6 & SSSF & 250 & Pasture \\
\hline F5 & SJU & $21^{\circ} 22^{\prime} 53^{\prime \prime S} 41^{\circ} 55^{\prime} 37^{\prime \prime} \mathrm{W}$ & 2.0 & SSSF & 200 & Pasture, tomato, eggplant, and cucumber \\
\hline F6 & SJU & $21^{\circ} 23^{\prime} 10^{\prime \prime} \mathrm{S} 41^{\circ} 55^{\prime} 15^{\prime \prime} \mathrm{W}$ & 6.6 & SSSF & 200 & Pasture and tomato \\
\hline F7 & TRJ & $22^{\circ} 04^{\prime} 20^{\prime \prime} \mathrm{S} 42^{\circ} 03^{\prime} 56^{\prime \prime} \mathrm{W}$ & 14.0 & DMOF & 710 & Pasture and urban area \\
\hline F8 & TRJ & $22^{\circ} 04^{\prime} 37^{\prime \prime} \mathrm{S} 42^{\circ} 04^{\prime} 00^{\prime \prime} \mathrm{W}$ & 12.0 & DMOF & 740 & Pasture, eucalyptus, and urban area \\
\hline F9 & TRJ & $22^{\circ} 04^{\prime} 31^{\prime \prime} \mathrm{S} 42^{\circ} 04^{\prime} 42^{\prime \prime} \mathrm{W}$ & 18.0 & DMOF & 825 & Pasture, eucalyptus, peach, kaki, and banana \\
\hline
\end{tabular}

$\mathrm{D}<5 \%$ and $\geqslant 2.5 \%$, the species is accessory (a), and when $\mathrm{D}<2.5 \%$, the species is occasional (oc). When analyzed together, these indices have been used to group the species into three categories $(\mathrm{Ct}): \mathrm{vf}+\mathrm{d}=$ common species, in $+\mathrm{oc}=$ rare species, and other combinations = intermediate species (adapted from Palma 1975).

To compare the diversity index among the euglossine bee community the estimated Shannon-Wiener were transformed 

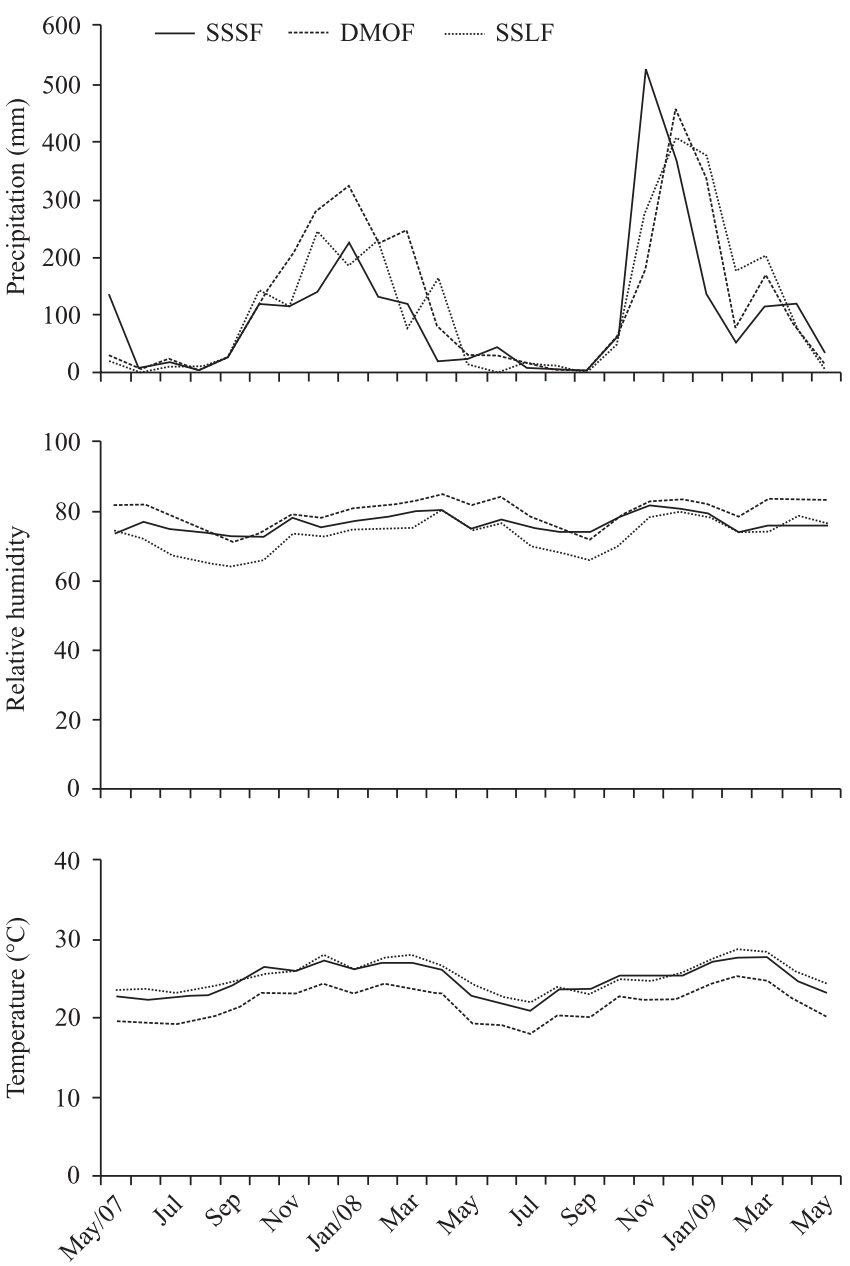

Fig. 2. Climate data from May/2007 to May/2009 for the three regions studied (source: INMET- National Meteorological Institute).

to exponential of the Shannon-Wiener index: $\exp \left(\mathrm{H}^{\prime}\right)$. In addition, the Jackknife procedure was performed to estimate the Shannon-Wiener index, resulting in a confidence interval of $95 \%$. These intervals were compared and non-overlapping intervals were considered significantly different (Zahl 1977). Estimates were performed using the program SPADE (Species Prediction and Diversity Estimation) (Chao \& Shen 2005).

The rarefaction curve for species richness was expressed as a function of 1000 randomization, as described by Magurran (2004). This analysis was performed with EcoSim 7 software (Gotelli \& Entsminger 2004). Curves were obtained by plotting the values simulated by EcoSim on the software Past 1.91 .

The Software EstimateS 8.0 (Colwell 2006) was employed for calculating the non-parametric richness estimators (Chao1, Jack1 and Bootstrap) to confirm the sample sufficiency.

The ordenation among the communities of euglossine bees in the study areas was performed by using Detrended Correspondence Analysis (DCA), from the matrix of abundance of individuals in each forest fragment sampled. The
DCA was employed because it is commonly applied to represent patterns of gradual replacement of species along environmental gradients (Ter Braak 1995). Later, the first two axes of DCA were used to check the relationship with precipitation, humidity, temperature and altitude of each area studied by Pearson's linear correlation. The axes of the DCA have also been used to investigate the relationship with the vegetational type using analysis of variance (ANOVA).

Spearman's correlation was conducted among abiotic (temperature, humidity, precipitation and elevation) and biotic (vegetation type) variables and the abundance of each species to verify the relation of the patterns of abundance in each fragment studied. These analyzes were performed with the aid of software Statistica 8.0.

\section{RESULTS}

Euglossine bee community in the small fragments. During the study period 1,558 male euglossine bees belonging to three genera and ten species were sampled in the nine forest fragments (Table II). The forest fragments with the highest abundance of bees were F5 (316 individuals), followed by F4, F6, and F3 (264, 243, 212 individuals, respectively), all fragments in submountainous semideciduous seasonal forest areas (SSSF). The fragments of dense mountainous ombrophilous forest (DMOF), however, presented the lowest abundance of bees (F9, 92 individuals; F8, 75, and F7, 68). In the fragments of semideciduous seasonal lowland forest (SSLF), the abundances were intermediate when compared with the other areas studied (F1, 159 individuals and F2, 129) (Table II).

Species richness varied from five to seven in each fragment (Table II). Euglossa cordata (Linnaeus, 1758), Euglossa securigera Dressler, 1982, Eulaema cingulata (Fabricius, 1804), and Eulaema nigrita Lepeletier, 1841 were common to all fragments studied. On the other hand, Euglossa annectans Dressler, 1982 only occurred in fragments F7 and F9, Euglossa pleosticta Dressler, 1982 in fragment F8, and Eulaema atleticana Nemésio, 2009 in F1. Individuals of Euglossa despecta Moure, 1968 were restricted to fragments of SSSF and Eulaema atleticana to fragment F1. Exaerete smaragdina (Guérin, 1844) was not sampled in DMOF fragments (Table II).

Eulaema nigrita was dominant in all seasonal semideciduous lowland forest and dense mountainous ombrofilous forest fragments, representing between $40 \%$ and $59 \%$ of the individuals sampled; Euglossa cordata was dominant in all SSSF fragments, where it was represented by $26 \%$ to $39 \%$ of the individuals (Table II). The euglossine bee communities presented uniformity varying between $\mathrm{J}=0.68$ and $\mathrm{J}=0.82$ in the fragments studied (Table II).

The diversity of species differed significantly among the studied areas, ranging from $\mathrm{H}^{\prime}=1.04$ in $\mathrm{F} 2$ to $\mathrm{H}^{\prime}=1.65$ in F4. The lowest diversity values were observed for the communities of the SSLF fragments and the highest values in the SSSF fragments (Table III). 
Table II. Composition, total abundance, richness, diversity, uniformity, and dominance (D), of the Euglossina species sampled trimesterally between May 2007 and May 2009 in nine fragments of Atlantic Forest in the Rio de Janeiro state, southeastern Brazil. SSLF- semideciduous seasonal lowland forest, SSSF- submountain semideciduous seasonal forest, and DMOF- dense mountainous ombrophilous forest. $\mathrm{Ct}$ : Category: $\mathrm{C}=$ common species, $\mathrm{I}=$ intermediate species, and $\mathrm{R}=$ rare species.

\begin{tabular}{|c|c|c|c|c|c|c|c|c|c|c|c|c|c|}
\hline \multirow{3}{*}{ Species } & \multicolumn{12}{|c|}{ Study Areas } & \multirow{3}{*}{ Total } \\
\hline & \multicolumn{3}{|c|}{ SSLF } & \multicolumn{5}{|c|}{ SSSF } & \multicolumn{4}{|c|}{ DMOF } & \\
\hline & F1 & $\mathrm{F} 2$ & $\mathrm{Ct}$ & F3 & $\mathrm{F} 4$ & F5 & F6 & $\mathrm{Ct}$ & F7 & F8 & F9 & $\mathrm{Ct}$ & \\
\hline Euglossa annectans Dressler & 0 & 0 & - & 0 & 0 & 0 & 0 & - & 3 & 0 & 11 & $\mathrm{C}$ & 14 \\
\hline E. cordata $(\mathrm{L})$. & 61 & 39 & $\mathrm{C}$ & 72 & 72 & 83 & 93 & $\mathrm{C}$ & 3 & 5 & 5 & $\mathrm{C}$ & 433 \\
\hline E. despecta Moure & 0 & 0 & - & 1 & 3 & 3 & 1 & $\mathrm{R}$ & 0 & 0 & 0 & - & 8 \\
\hline E. fimbriata Rebêlo \& Moure & 0 & 0 & - & 9 & 36 & 44 & 18 & $\mathrm{C}$ & 0 & 4 & 1 & $\mathrm{R}$ & 112 \\
\hline E. pleosticta Dressler & 0 & 0 & - & 0 & 0 & 0 & 0 & - & 0 & 1 & 0 & $\mathrm{R}$ & 1 \\
\hline E. securigera Dressler & 1 & 2 & $\mathrm{R}$ & 55 & 37 & 76 & 42 & $\mathrm{C}$ & 8 & 17 & 8 & $\mathrm{C}$ & 246 \\
\hline Eulaema atleticana Nemésio & 1 & 0 & $\mathrm{R}$ & 0 & 0 & 0 & 0 & - & 0 & 0 & 0 & - & 1 \\
\hline E. cingulata (Fabricius) & 19 & 7 & $\mathrm{C}$ & 26 & 55 & 26 & 25 & $\mathrm{C}$ & 22 & 18 & 23 & $\mathrm{C}$ & 221 \\
\hline E. nigrita Lepeletier & 67 & 76 & $\mathrm{C}$ & 49 & 60 & 82 & 62 & $\mathrm{C}$ & 32 & 30 & 44 & $\mathrm{C}$ & 502 \\
\hline Exaerete smaragdina (Guérin) & 10 & 5 & $\mathrm{C}$ & 0 & 1 & 2 & 2 & $\mathrm{R}$ & 0 & 0 & 0 & - & 20 \\
\hline Abundance & 159 & 129 & & 212 & 264 & 316 & 243 & & 68 & 75 & 92 & & 1558 \\
\hline Richness & 6 & 5 & & 6 & 7 & 7 & 7 & & 5 & 6 & 6 & & 10 \\
\hline Diversity (H') & 1.25 & 1.04 & & 1.49 & 1.65 & 1.61 & 1.52 & & 1.28 & 1.48 & 1.418 & & 1.61 \\
\hline Uniformity $(\mathrm{J})$ & 0.68 & 0.64 & & 0.80 & 0.80 & 0.82 & 0.78 & & 0.78 & 0.80 & 0.77 & & 0.70 \\
\hline Dominance (D) & 0.42 & 0.59 & & 0.3 & 0.3 & 0.26 & 0.39 & & 0.47 & 0.40 & 0.48 & & 0.33 \\
\hline
\end{tabular}

Table III. Comparison of species diversity of euglossine bees in nine small forest fragments in the Rio de Janeiro state, southeastern Brazil. Diversity was calculated from the exponential $\left[\exp \left(\mathrm{H}^{\prime}\right)\right]$ and estimated $\left(\mathrm{H}^{\prime}\right)$ Shannon-Wiener index. LL CI95\% = lower limit of the confidence interval; UL CI95\% = upper limit of the confidence interval. The overwrite lowercase letters to the estimated $\mathrm{H}^{\prime}$ indicated differences between the areas studied.

\begin{tabular}{ccccc}
\hline Areas & Exp. H' & H' estimated $^{\prime}$ & LL CI 95\% & UL CI 95\% \\
\hline F4 & 5.21 & $1.65^{\mathrm{a}}$ & 1.58 & 1.71 \\
F5 & 5.00 & $1.61^{\mathrm{ab}}$ & 1.55 & 1.67 \\
F6 & 4.59 & $1.52^{\mathrm{abc}}$ & 1.43 & 1.61 \\
F3 & 4.42 & $1.49^{\mathrm{bc}}$ & 1.41 & 1.57 \\
F8 & 4.4 & $1.48^{\mathrm{abcd}}$ & 1.3 & 1.66 \\
F9 & 4.08 & $1.41^{\mathrm{abcd}}$ & 1.23 & 1.58 \\
F7 & 3.59 & $1.28^{\mathrm{cde}}$ & 1.09 & 1.47 \\
F1 & 3.48 & $1.25^{\mathrm{de}}$ & 1.12 & 1.37 \\
F2 & 2.83 & $1.04^{\mathrm{e}}$ & 0.88 & 1.19 \\
\hline
\end{tabular}

The rarefaction curves for the nine fragments analyzed demonstrated sampling sufficiency for almost all the areas, with the exceptions of F1 and F6 (Fig. 3), which is confirmed by richness estimators (Table IV). The values of the richness curves indicated no significant difference in the number of euglossine species among the nine small forest fragments studied (Fig. 3).

The curves obtained for species importance (Rank-Abundance Plot) did not present significant difference compared with all the fragments (according to the KolmogorovSmirnov Test, $\mathrm{p}>0.05$ ) (Fig. 4). In general, observations showed that most species were represented by more than $10 \%$ of the individuals in each area resulting in higher number of common species than rare or intermediate species (Table II).

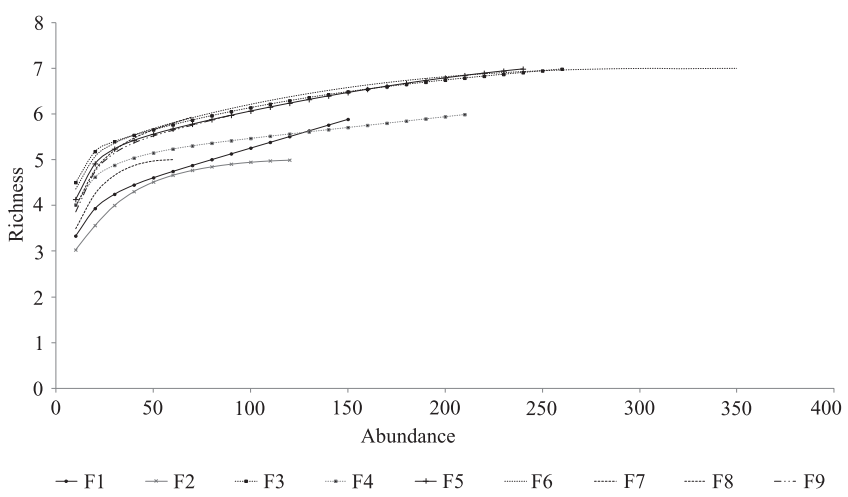

Fig. 3. Rarefaction curves with 1,000 simulations for species richness for nine small forest fragments of the Atlantic Forest, Rio de Janeiro state, southeastern Brazil.

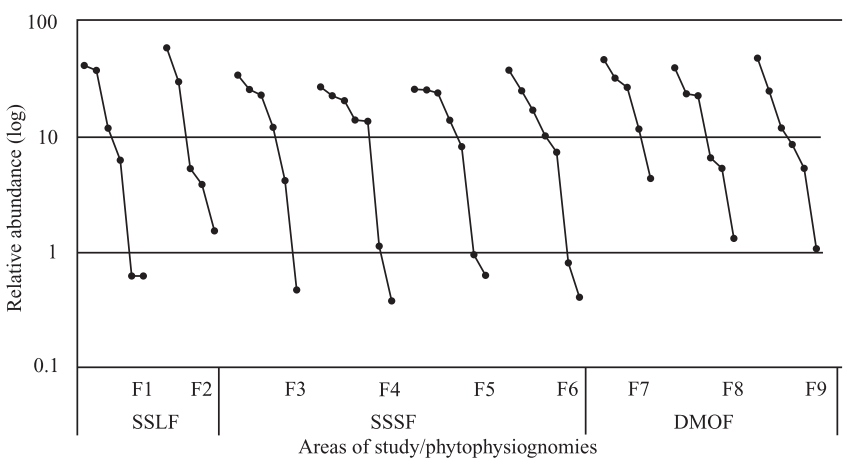

Fig. 4. Species importance (Rank-abundance plot, Whittaker [1965]) according to relative abundance of euglossine bees attracted to aromatic baits between May/2007 and May/2009 in nine small forest fragments of the Atlantic Forest, Rio de Janeiro state, southeastern Brazil. 
Table IV. Richness estimators for the euglossine bees in nine small forest fragments in the Rio de Janeiro state, southeastern Brazil, between May 2007 and May 2009.

\begin{tabular}{|c|c|c|c|c|c|c|c|c|c|}
\hline \multirow{2}{*}{ Richness estimator } & \multicolumn{2}{|c|}{ SSLF } & \multicolumn{4}{|c|}{ SSSF } & \multicolumn{3}{|c|}{ DMOF } \\
\hline & $\mathrm{F} 1$ & $\mathrm{~F} 2$ & F3 & F4 & F5 & F6 & F7 & F8 & F9 \\
\hline Jack1 & $7.8 \pm(1.2)$ & $5.9 \pm(0.9)$ & $6.9 \pm(0.9)$ & $6.0 \pm(0)$ & $7.9 \pm(0.9)$ & $8.8 \pm(1.8)$ & $6.9 \pm(0.9)$ & $5.0 \pm(0)$ & $6.9 \pm(0.9)$ \\
\hline Chaol & $7.0 \pm(2.2)$ & $5.0 \pm(0)$ & $6.0 \pm(0.5)$ & $6.0 \pm(0)$ & $7.0 \pm(0)$ & $7.0 \pm(0.3)$ & $6.0 \pm(0.5)$ & $5.0 \pm(0)$ & $6.0 \pm(0.5)$ \\
\hline Bootstrap & $6.7 \pm(0)$ & $5.5 \pm(0)$ & $6.3 \pm(0)$ & $6.1 \pm(0)$ & $7.4 \pm(0)$ & $7.7 \pm(0)$ & $6.4 \pm(0)$ & $5.2 \pm(0)$ & $6.4 \pm(0)$ \\
\hline
\end{tabular}

The ordination methods (Detrended Correspondence Analysis) among the euglossine bee communities studied resulted in three groups that coincide with the phytophysiognomies analyzed (Fig. 5). The eigenvalue in the axes 1 and 2 were, respectively, 0.16 and 0.11 . The variance percentage explained by the axes 1 was $45.27 \%$ and by axes 2 was $31.76 \%$.

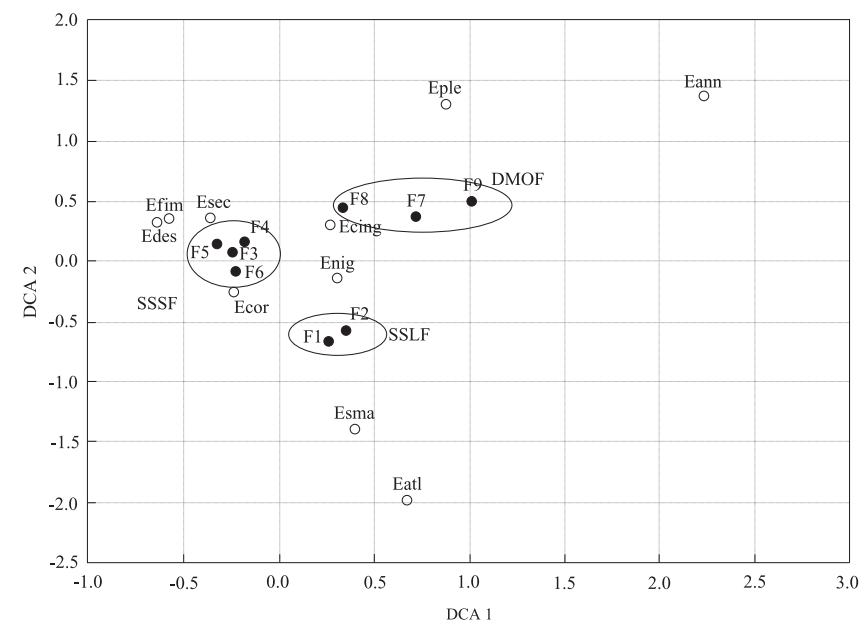

Fig. 5. Diagram of Detrended Correspondence Analysis (DCA) for areas and for species sampled in small forest fragments of the Atlantic Forest, Rio de Janeiro state, southeastern Brazil. Eann: Euglossa annectans, Ecor: Euglossa cordata, Edes: Euglossa despecta, Efim: Euglossa fimbriata, Eple: Euglossa pleosticta, Eatl: Eulaema atleticana, Ecing: Eulaema cingulata, Enig: Eulaema nigrita e Esma: Exaerete smaragdina.

The correlation between the first axes of the DCA and abiotic variables studied showed a significant negative influence of temperature $(r=-0.719, p=0.029)$, and positive of humidity and altitude $(r=0.852$ and $\mathrm{p}=0.003, \mathrm{r}=0.675$ and $\mathrm{p}=0.004$, respectively). The second axis of DCA was significantly influenced negatively with temperature $(\mathrm{r}=-0.696, \mathrm{p}=$ $0.037)$ and positively with precipitation and altitude $(r=0.964$, $\mathrm{p}=0.000$; and $\mathrm{r}=0.805, \mathrm{p}=0.000$, respectively). ANOVA between the axes of the DCA and phytophysiognomies analyzed showed effect on the ordination of euglossine bee communities from the first $(F 2,6=7.9935, p=0.02032)$ and the second axis $(\mathrm{F} 2,6=59,975, \mathrm{p}=0.00011)$ of the DCA.

The correlations between the abundance of species and environmental variables analyzed revealed that Euglossa annectans has significant positive relationship with altitude $(\mathrm{r}=0.69)$ and marginally with the other variables analyzed. Abundances of Euglossa cordata, E. despecta, E. fimbriata,
E. securigera and Eulaema cingulata were negatively related to relative humidity $(\mathrm{r}=-0.94,-0.89,-0.72,-0.67$ and -0.72 , respectively) and had no relation with the other variables (Table V). On the other hand Eulaema nigrita and Exaerete smaragdina showed significant relationship with all variables analysed, except the humidity (Table V).

Table V. Spearman correlation between the abundance of euglossine species and abiotic variables observed in nine small forest fragments of the Atlantic Forest in the Rio de Janeiro state, southeastern Brazil, between May 2007 and May 2009.

\begin{tabular}{lcccc}
\hline \multirow{2}{*}{ Species } & \multicolumn{4}{c}{ Abiotics variables } \\
\cline { 2 - 5 } & Temperature & Humididy & Precipitation & Altitude \\
\hline Euglossa annectans & -0.66 & 0.66 & 0.66 & $0.69 *$ \\
E. cordata & 0.51 & $-0.94 * *$ & -0.51 & -0.52 \\
E. despecta & 0.18 & $-0.89 * *$ & -0.18 & -0.17 \\
E. fimbriata & -0.07 & $-0.72^{*}$ & 0.07 & 0.05 \\
E. pleosticta & -0.44 & 0.44 & 0.44 & 0.35 \\
E. securigera & -0.19 & $-0.67 *$ & 0.19 & 0.10 \\
Eulaema atleticana & 0.51 & 0.07 & -0.51 & -0.55 \\
E. cingulata & -0.07 & $-0.72 *$ & 0.07 & 0.12 \\
E. nigrita & $0.83^{* *}$ & -0.61 & $-0.83^{* *}$ & $-0.85^{* *}$ \\
Exaerete smaragdina & $0.88^{* *}$ & -0.38 & $-0.88^{* *}$ & $-0.88^{* *}$ \\
\hline
\end{tabular}

\section{DISCUSSION}

Species richness, expressed by rarefaction curves, demonstrated no significant differences among the nine fragments studied in the three phytophysiognomies. Nevertheless, species richness was lower than those registered in other studies of Atlantic Forest fragments. Those studies revealed 19 and 17 species (richness corrected according to the taxonomic changes indicated by Dr. Gabriel A.R. Melo) in dense sub-mountainous and lowland ombrophilous forest (Tonhasca et al. 2002; Ramalho et al. 2009, respectively), 14 species in fragments of sub-mountainous semideciduous seasonal forest (Nemésio \& Silveira 2010), and 11 species in semideciduous seasonal lowland forest (Aguiar \& Gaglianone 2008a). Species loss in small fragments has commonly been reported in studies on the effects of fragmentation on euglossine bee communities (Powell \& Powell 1987; Sofia \& Suzuki 2004; Ramalho et al. 2009). In small fragments of Atlantic Forest the low species richness relative to larger areas was also observed by Ramalho et al. (2009), who encountered 8 species in an area of 19 ha, a richness similar to that found in small fragments in urban areas (Bezerra \& Martins 2001). 
The dominance of Eulaema nigrita and Euglossa cordata, as observed in this study, was also registered in other Atlantic Forest fragments, both for well-preserved areas (Aguiar \& Gaglianone 2008a; Ramalho et al. 2009) as well as disturbed ones (Viana et al. 2006; Ramalho et al. 2009). In small fragments, the high dominance of few species could be worrying, especially in light of susceptibility to a loss in habitat diversity which can lead to reduced resource availability (Connor \& McCoy 1979). This factor frequently results in increased competition and rare species loss due to the consumption of food resources and/or offspring by dominant species (Schaffer et al. 1983; Roubik et al. 1986). On the other hand, dominant species are characterized as generalists in terms of food resources for their habit of visiting flowers of many different groups of plants (Winston 1987; Ramirez et al. 2002).

In the context of a global decline in pollinators (Potts et al. 2010), generalist species are extremely important for the pollination of native and cultivated plants (Ghazoul 2005; Gressler et al. 2006; Aguiar \& Gaglianone 2008b; Benevides et al. 2009). Thus the conservation of these pollinators, even when associated with low species richness in small fragments, is important because it can ensure the pollination of many plant species, including those in surrounding agricultural areas. Benevides et al. (2009) observed increased richness in pollinators of Passiflora edulis f. flavicarpa DC (maracujáamarelo), such as Centridini and Euglossina, in addition to Xylocopa, in cultivated areas near forest fragments. This result was related to bee dependency on nesting and feeding resources in forest areas. In the same way, Chacoff \& Aizen (2006) observed that the abundance, richness, and frequency of flower visitors in orange plantations dropped significantly as distance from forest fragments increased. The authors considered remaining stands of forest as a source of flower visitors that may represent effective pollinators in agricultural areas. While agricultural areas may offer temporary sources of pollen and nectar (Steffan-Dewenter \& Kuhn 2003), they do not furnish adequate habitats for nesting (Chacoff \& Aizen 2006). This deficiency can be compensated with remaining forest areas that can supply year-round nesting and floral resources (Lagerlöf et al. 1992).

Our data suggest that small Atlantic Forest fragments possess limited Euglossina fauna, essentially species considered resistant to open, altered, and/or disturbed areas, such as Euglossa cordata, Eulaema cingulata, and E. nigrita (see Peruquetti et al.1999; Aguiar \& Gaglianone 2008a; Ramalho et al. 2009). However, species considered more stringent like Eulaema atleticana and Euglossa annectans (Milet-Pinheiro \& Schlindwein 2005; Nemésio 2009) were sampled in some of these small areas. The presence of these species highlights the importance of conserving these small fragments in order to preserve the diversity of euglossine bees.

The relative importance curve indicates that the most abundant species contributed with similar percentages when comparing with the species with lower abundances. This pattern is not commonly observed in euglossine bee communi- ties. A large quantity of studies illustrate that the individual relative abundance can differ widely among species (Neves \& Viana 1997; Peruquetti et al. 1999; Aguiar \& Gaglianone 2008a; Ramalho et al. 2009), and the communities present few species that are clearly dominant and many species that are not common (Roubik \& Hanson 2004). The relative abundance distribution pattern observed in this study is probably a reflection of rare species loss due to reduced areas. Species potentially less competitive or the most sensitive species to the effects of forest fragmentation probably could not survive in these small fragments. Similar results have been observed by Silva et al. (2009) in sandbank (restinga) areas in northeastern Maranhão State and by Nemésio \& Silveira (2007) in the Mangabeira Park, an urban fragment in the city of Belo Horizonte-MG. This pattern indicates that only species tolerant of disturbed areas are able to inhabit these open areas and suggests that rarer or less abundant species may have become extinct in these fragments.

The loss of euglossine species in small forest fragments is most evident when comparing these results with studies of Aguiar (2011) in larger forest fragments better preserved in the same region and phytophysiognomies in the state of Rio de Janeiro. Aguiar (op. cit.) recorded in those areas a richness around $45 \%$ higher in seasonal semideciduous lowland forest (SSLF), about $40 \%$ higher in areas of seasonal semideciduous submontane forest (SSSF) and 55\% higher in areas of dense mountainous ombrophile forest (DMOF), comparing with the small fragments. All these larger areas have more than 900 ha and are considered well preserved or in mature stage of regeneration (Dan et al. 2010, Nascimento, M.T. personal communication).

Detrended correspondence analysis (DCA) formed three groups, which coincide with the phytophysiognomies studied. The occurrence of Euglossa annectans, associated with higher altitudes and marginally with lower temperature and higher humidity and precipitation, demonstrates the habitat preference of this species, as observed in the region of DMOF. Other studies also showed the presence of this species at higher altitudes in the state of São Paulo (Garófalo et al. 1998) and Minas Gerais (Nemésio \& Silveira 2007), however in southern Brazil it was also recorded in less elevated areas (Cortopassi-Laurino et al. 2009), but in mild temperatures, like those found in DMOF. The abundance pattern of Euglossa securigera and E. fimbriata and the occurrence of $E$. despecta only in SSSF resulted in the grouping of fragments of this phytophysiognomy in the performed analysis. Those species occurred in higher abundances in fragments with lower humidity. Gaglianone \& Aguiar (2008a) observed that the same three species were highly abundant in the dry season in the region. This was pattern also observed by Silva \& Rêbelo (1999) for Euglossa securigera in areas of Amazon rainforest in Maranhão state, confirming the relationship found in this study. However, this pattern differs of the areas of Atlantic Forest in southern Brazil, where Euglossa fimbriata, for example, has activity throughout the year without evident seasonal variations (Sofia et al. 2004). The third 
group is formed by the greater abundance of Exaerete smaragdina and the occurrence of Eulaema atleticana in the fragments of SSLF. These species showed a significant negative relationship with precipitation and altitude, and in contrast showed a positive relationship with temperature.

The performed analysis reinforced the role of phytophysiognomy as determinant in the composition, abundance and distribution patterns of the euglossine species. The reduced number of species encountered, mostly characterized by species of wide-ranging geographic distribution and resistance to the adverse conditions of the small fragments (boundary effect and resource reduction), may well have relevance in the alteration of community structure, leading to the high faunal similarity among distinct regions.

The environmental variables considered in the correlation analysis revealed that the humidity, temperature and altitude showed significant influence on the DCA axis 1, while the precipitation has not demonstrated this influence. In the second axis of DCA only the humidity showed no significant correlation. Environmental characteristics such as altitude, precipitation, and temperature may have influenced the occurrence of Euglossina (see Nemésio \& Silveira 2007; Cortopassi-Laurino et al. 2009). According to Ramirez et al. (2002), altitude is one of the main factors that influences the geographical distribution of euglossine bees. Dias (2007) also showed significant differences in the euglossine bee species composition over an altitude gradient (50-2150 m), though richness and abundance were unaffected. In addition to these factors, resource availability, competition, and historical factors were cited by other authors as important players for determining euglossine bee richness and species composition (Rosenzweig 1995; Roubik \& Hanson 2004; Souza et al. 2005; Silva et al. 2009).

Thus the results presented in this study demonstrate that small forest fragments, as the studied areas with up to 18ha, can support populations of euglossine bee species that are considered resistant to open and/or disturbed areas. Our results also indicate that the conservation of these small fragments has to be regarded important, especially in areas that are regenerating and in regions with agricultural matrices where these bees can function as important pollinators. The presence of these species in small fragments, however, offers no guarantee for their preservation since euglossine populations in small fragments may be represented by populations left over from large areas in past generations that are now on the road to extinction (Nemésio \& Silveira 2007).

\section{ACKNOWLEDGMENTS}

We thank Gabriel A. R. Melo for his help in identification of the bees; INMET for climatic data; geoprocessing sector of LCA-UENF for the map; Frederico Machado Teixeira, Marcelita França Marques, Mariana Scaramussa Deprá and Giselle Braga Menezes for their help in the field; FAPERJ for fellowships to the first author. We also thank the financial support by Procad/Capes (158/07), Rio Rural/
SEAPPA/GEF and the anonymous referees and editor for important criticisms and suggestions to the manuscript.

\section{REFERENCES}

Aguiar, W. M. \& M. C. Gaglianone. 2008a. Comunidade de Abelhas Euglossina (Hymenoptera: Apidae) em Remanescentes de Mata Estacional Semidecidual sobre Tabuleiro no Estado do Rio de Janeiro. Neotropical Entomology 37: 118-125.

Aguiar, W. M. \& M. C. Gaglianone. 2008b. Comportamento de abelhas visitantes florais de Lecythis lurida (Lecythidaceae) no norte do estado do Rio de Janeiro. Revista Brasileira de Entomologia 52: 277-282.

Aguiar, W. M. 2011. Estrutura das comunidades de abelhas Euglossina (Hymenoptera; Apidae) e variabilidade genética de Eulaema cingulata (Fab.) em fragmentos florestais no estado do Rio de Janeiro. Tese de doutorado, Universidade Estadual do Norte Fluminense. 146 p.

Aizen, M. A. \& P. Feinsinger. 2003. Bees not to be? Responses of insect pollinator faunas and flower pollination to habitat fragmentation. p. 111-129. In: G. A. Bradshaw \& P. A. Marquet (ed.). How landscapes change: human disturbance and ecosystem fragmentation in the Americas. Berlin, Springer-Verlag, xxi + 384p.

Becker, P.; J. S. Moure \& F. J. A Peralta. 1991. More about euglossini bees in Amazonian forest fragments. Biotropica 23: 586-591.

Benedick, S.; J. K. Hill; N. Mustaffa; V. K. Chey; M. Maryati; J. B. Searle; M. Schilthuizen \& K. C. Hamer. 2006. Impacts of rain forest fragmentation on butterflies in northern Borneo: species richness, turnover and the value of small fragments. Journal of Applied Ecology 43: 967-977.

Benevides, C. R.; M. C. Gaglianone \& M. Hoffmann. 2009. Visitantes florais do maracujá-amarelo (Passiflora edulis f. flavicarpa Deg. Passifloraceae) em áreas de cultivo com diferentes proximidades a fragmentos florestais na região Norte Fluminense, RJ. Revista Brasileira de Entomologia 53: 415-421.

Bezerra, C. P. \& C. F. Martins. 2001. Diversidade de Euglossinae (Hymenoptera; Apidae) em dois fragmentos de Mata Atlântica localizados na região urbana de João Pessoa, Paraíba, Brasil. Revista Brasileira de Zoologia 18: 823-825.

Bodenheimer, F. S. 1955. Précis d'écologie animale. Paris: Payot, 315 p.

Bodin, Ö.; M. Tengö; A. Norman; J. Lundberg \& T. Elmqvist. 2006. The value of small size: loss of forest patches and threshold effects on ecosystem services in southern Madagascar. Ecological Applications 16: $440-451$

Brosi, B. J. 2009. The effects of forest fragmentation on euglossine bee communities (Hymenoptera: Apidae: Euglossini). Biological Conservation 142: 414-423.

Cameron, S. A. 2004. Phylogeny and biology of neotropical orchid bees (Euglossini). Annual Review of Entomology 49: 377-404.

Chacoff, N. P \& M. A. Aizen. 2006. Edge effects on flower visiting insects in grapefruit plantations bordering premontane subtropical forest. Journal of Applied Ecology 43: 18-27.

Chao, A. \& T. -J. Shen. 2005. Program SPADE (species prediction and diversity estimation). Program and user's guide. (2003-2005). Disponível em: http://chao.stat.nthu.edu.tw/download.html (acessado em 21 de novembro de 2011).

Connor, E. F. \& E. D. McCoy. 1979. The statistics and biology of the speciesarea relationship. The American Naturalist 113: 791-833.

Colwell, R. K. 2006. EstimateS: Statistical Estimation of Species Richness and Shared Species from Samples. Version 8.20. Software and User's Guide.

Cortopassi-Laurino, M.; A. Zillikens \& J. Steiner. 2009. Pollen sources of the orchid bee Euglossa annectans Dressler 1982 (Hymenoptera: Apidae, Euglossini) analyzed from larval provisions. Genetics and Molecular Research 8: 546-556.

Dan, M. L.; J. M. A. Braga \& M. T. Nascimento. 2010. Estrutura da comunidade arbórea de fragmentos de floresta estacional semidecidual na bacia hidrográfica do rio São Domingos, Rio de Janeiro, Brasil. Rodriguésia 61:1-18. 
Dias, R. de L. 2007. Abelhas Euglossina das serras do norte do estado do Amazonas. Dissertação de mestrado, Manaus, Universidade Federal do Amazonas, ix $+40 \mathrm{p}$

Dressler, R. L. 1982. Biology of the orchid bees (Euglossini). Annual Review of Ecology and Systematics 13: 373-394.

Dunning, J. B.; B. J. Danielson \& H. R. Pulliam. 1992. Ecological processes that affect populations in complex landscapes. Oikos 65: 169-175

Estrada, A. \& R. Coates-Estrada. 2002. Dung beetles in continuous forest, forest fragments and in an agricultural mosaic habitat island at Los Tuxtlas, Mexico. Biodiversity and Conservation 11: 1903-1918.

Fahrig, L. 2003. Effects of habitat fragmentation on biodiversity. Annual Reviews of Ecology and Systematics 34: 487-515.

Fischer, J. \& D. B. Lindenmayer. 2002. Small patches can be valuable for biodiversity conservation: two case studies on birds in southeastern Australia. Biological Conservation 106: 129-136.

Fundação SOS Mata Atlântica \& INPE. 2008. Atlas dos remanescentes florestais da Mata Atlântica no período de 2000-2005: relatório final. São Paulo, Fundação SOS Mata Atlântica/INPE.

Fundação SOS Mata Atlântica \& INPE. 2011. Atlas dos remanescentes florestais da Mata Atlântica no período de 2008-2010: relatório final. São Paulo, Fundação SOS Mata Atlântica/INPE.

Garófalo, C. A.; E. Camillo; S. C. Augusto; B. M. V. Jesus \& J. C. Serrano. 1998. Nest structure and communal nesting in Euglossa (Glossura) annectans Dressler (Hymenoptera, Apidae, Euglossini). Revista Brasileira de Zoologia 15: 589-596.

Ghazoul, J. 2005. Buzziness as usual? Questioning the global pollination crisis. Trends in Ecology and Evolution 20: 367-373.

Gotelli, N. J. \& G. L. Entsminger. 2004 EcoSim: Null models software for ecology. Version 7.0. Acquired Intelligence Inc. \& Kesey-Bear. Jericho, VT 05465. http://garyentsminger.com/ecosim/index.htm.

Goulson, D.; G. C. Lye \& B. Darvill. 2008. Decline and conservation of bumble bees. Annual Review of Entomology 53: 191-208.

Gressler, E.; M. A. Pizo \& P. C. Morellato. 2006. Polinização e dispersão de sementes em Myrtaceae do Brasil. Revista Brasileira de Botânica 29: 509-530.

Lagerlof, J.; J. Stark, \& B. Svensson. 1992. Margins of agricultural fields as habitats for pollinating insects. Agriculture, Ecosystem and Environment 40: 117-124.

Magurran, A. E. 2004. Measuring biological diversity. Oxford, Blackwell Publishing, vii $+256 \mathrm{p}$.

Maués, M. M. 2002. Reprodutive phenology and pollination of the Brazil nut tree (Bertholletia excelsa Humb. \& Bonpl., Lecythidaceae) in Eastern Amazonia. 245-254. In: P. Kevan \& V. L. Imperatriz Fonseca (eds.). Pollinating Bees - The Conservation Link Between Agriculture and Nature - Brasilia, Ministry of Environment, 313 p.

Milet-Pinheiro, P. \& C. Schlindwein. 2005. Do euglossine males (Apidae, Euglossini) leave tropical rainforest to collect fragrances in sugarcane monocultures? Revista Brasileira de Zoologia 22: 853-858.

Morato, E. F. 1994. Abundância e riqueza de machos de Euglossini (Hymenoptera: Apidae) em mata de terra firme e áreas de derrubada, nas vizinhanças de Manaus (Brasil). Boletim do Museu Paraense Emílio Goeldi, série Zoologia, 10: 95-105.

Mori, S. A. \& J. D. Boeke. 1987. Pollination. Chapter 12 In: S. A. Mori \& Collaborators (eds). The Lecythidaceae of a lowland neotropical forest: La Fuméc Mountain, French Guiana. Memoirs of the New York Botanical Garden 44: 137-155.

Myers, N.; R. A. Myttermeier; C. G. Myttermeier; G. A. B. Fonseca \& J. Kent. 2000. Biodiversity hotsposts for conservation priorities. Nature 403: $853-858$.

Moure, J. S.; G. A. R. Melo \& L. R. R. Faria Jr. 2008. Catalogue of Bees (Hymenoptera, Apoidea) in the Neotropical Region. In: Moure, J. S., Urban, D. \& Melo, G. A. R. (Orgs) - online version. Available at http://www.moure.cria.org.br/catalogue. (accessed 20 October 2011).

Nemésio, A. 2009. Orchid bees (Hymenoptera: Apidae) of the Brazilian Atlantic Forest. Zootaxa 2041: 1-242.

Nemésio, A. \& F. A. Silveira. 2007. Orchid bee fauna (Hymenoptera: Apidae: Euglossina) of Atlantic Forest fragments inside an urban area in southeastern Brazil. Neotropical Entomology 36: 186-191.

Nemésio, A. \& F. A. Silveira 2010. Forest Fragments with Larger Core Areas Better Sustain Diverse Orchid Bee Faunas (Hymenoptera: Apidae: Euglossina). Neotropical Entomology 39: 555-561.

Neves, E. L. das \& B. F. Viana. 1997. Inventário da fauna de Euglossinae (Hymenoptera, Apidae) do baixo sul da Bahia, Brasil. Revista Brasileira de Zoologia 14: 831-837.

Palma, S. G. 1975. Contribuitión al studio de los Sifonoforos encontrados frente a la costa de Valparaiso. Aspectos ecológicos. Memorias del Segundo Simposio. Latinoamericano de Oceanografia Biològica. University de Oriente Cumaná, Venezuela 2: 119-133.

Peruquetti, R. C.; L. A. de O. Campos; C. D. P. Coelho; C. V. M. Abrantes \& L. C. de O. Lisboa. 1999. Abelhas Euglossini (Apidae) de áreas de Mata Atlântica: abundância, riqueza e aspectos biológicos. Revista Brasileira de Zoologia 16 (Supl. 2): 101-118.

Potts, S. G.; J. C. Biesmeijer; C. Kremen; P. Neumann; O. Schweiger \& W. E. Kunin. 2010. Global pollinator declines: trends, impacts and drivers. Trends in Ecology and Evolution 25: 345-353.

Powell, A. H. \& G. V. N. Powell. 1987. Population dynamics of male euglossine bees in Amazonian forest fragments. Biotropica 19: 176-179.

Ramalho, A. V.; M. C. Gaglianone \& M. L. Oliveira. 2009. Comunidades de abelhas Euglossina (Hymenoptera, Apidae) em fragmentos de Mata Atlântica no Sudeste do Brasil. Revista Brasileira de Entomologia 53: $95-101$.

Ramírez, S.; R. L. Dressler \& M. Ospina. 2002. Abejas euglosinas (Hymenoptera: Apidae) de la Región Neotropical: Listado de especies con notas sobre su biología. Biota Colombiana 3: 7-118.

Ricketts, T. H. 2004. Tropical forest fragments enhance pollinators activity in nearby coffee crops. Conservation Biology 18: 1262-1271.

Rizzini, C. T. 1979. Tratado de fitogeografia do Brasil. Volume 2. Aspectos Ecológicos. São Paulo, Hucitec/Edusp, 474 p.

Rocha, C. F. D.; H. G. Bergalho; M. A. S. Alves \& M. V. Sluys. 2003. A biodiversidade nos grandes remanescentes florestais do Estado do Rio de Janeiro e nas restingas da Mata Atlântica. São Carlos, Editora RIMA, $134 \mathrm{p}$

Rosenzweig, M. L. 1995. Species Diversity in Space and Time. New York, Cambridge University Press, $\mathrm{xx}+436 \mathrm{p}$.

Roubik, D. W. \& P. E. Hanson. 2004. Orchids bees of Tropical America: Biology and Field Guide. Santo Domingo de Heredia, INBio Press, $352 \mathrm{p}$.

Roubik, D. W.; J. E. Moreno; C. Vergara \& D. Wittmann. 1986. Sporadic food competition with the African honey bee: projected impact on Neotropical social bees. Journal of Tropical Ecology 2: 97-111.

Schaffer, W. M.; D. W. Zeh; S. L. Buchmann; S. Kleinhaus; M. V. Chaffer \& J. Antrim,. 1983. Competition for nectar between introduced honeybees and native North American bees and ants. Ecology 64: 564-577.

Silva, F. S.; J. M. M. Rebêlo. 1999. Euglossine bees (Hymenoptera: Apidae) of Buriticupu, Amazonia of Maranhão, Brazil. Acta Amazônica 29: $587-599$.

Silva, O.; M. M. C. Rego; P. M. C. Albuquerque \& M. C. Ramos. 2009. Abelhas Euglossina (Hymenoptera: Apidae) em Área de Restinga do Nordeste do Maranhão Neotropical Entomology 38: 186-196.

Silveira, F. A.; G. A. R. Melo \& E. A. B. Almeida. 2002. Abelhas Brasileiras, Sistemática e Identificação. Belo Horizonte, F. A. Silveira. 253 p.

Sofia, S. H. \& K. M. Suzuki. 2004. Comunidades de machos de abelhas Euglossina (Hymenoptera: Apidae) em fragmentos florestais no Sul do Brasil. Neotropical Entomology 33: 693-702.

Sofia, S. H.; A. M. Santos; C. R. M. Silva. 2004. Euglossine bees (Hymenoptera, Apidae) in a remnant of Atlantic Forest in Paraná State, Brazil. Iheringia, Série Zoologia, 94: 217-222.

Souza, A. K. P.; M. I. M. Hernández \& C. F. Martins. 2005. Riqueza, abundância e diversidade de Euglossina (Hymenoptera, Apidae) em três áreas da Reserva Biológica Guaribas, Paraíba Brasil. Revista Brasileira de Zoologia 22: 320-325

Steffan-Dewenter, I. \& A. Kuhn. 2003. Honeybee foraging in differentially structured landscapes. Proceedings of the Royal Society of London B 270: $569-575$. 
Ter Braak, C. J. F. 1995. Ordination. Data Analysis in Community and Landscape Ecology. p. 91-173. In: R. H. G. Jongman, C.J.F. Ter Braak \& O. F. R. Van Torgeren (eds.). Data analysis in community and landscape ecology. Chicago, Cambridge University Press, xxii + 299 p.

Tonhasca, A.; J. L. Blackmer \& G. S. Albuquerque. 2002. Abundance and diversity of euglossine bees in the fragmented landscape of the Brazilian Atlantic Forest. Biotropica 34: 416-422.

Tscharntke, T.; I. Steffan-Dewenter; A. Kruess \& C. Thies. 2002. Contribution of small habitat fragments to conservation of insect communities of grassland-cropland landscapes. Ecological Applications 12: 354363.

Veloso, H. P.; A. L. R. Rangel Filho \& J. C. A. Lima. 1991. Classificação da vegetação brasileira, adaptada a um sistema universal. Rio de Janei- ro, IBGE, $124 \mathrm{p}$.

Viana, B. F.; A. M. C. Melo \& P. D. Drumond. 2006. Variação na estrutura do habitat afetando a composição de abelhas e vespas solitárias em remanescentes florestais urbanos de Mata Atlântica no nordeste do Brasil. Sitientibus Série Ciências Biológicas 6: 282-295.

Whittaker, R. H.1965. Dominance and diversity in land plant communities. Science 147: 250-260.

Winfree, R.; R. Aguilar; D. P. Vazquez; G. Lebuhn \& M. A. Aizen. 2009. A meta-analysis of bees' responses to anthropogenic disturbance. Ecology 90: $2068-2076$.

Winston, M. L. 1987. The biology of the honeybee. Cambridge, Harvard University Press, $281 \mathrm{p}$.

Zahl, S. 1977. Jackknifing an index of diversity. Ecology 58: 907-913. 